\title{
Decision Making: A Significant Indicator for Economic Empowerment of Women
}

\author{
M. Milcah Paul ${ }^{1}$, Dr. M. Chaitanya Kumari ${ }^{2}$ \\ ${ }^{1}$ Research Scholar, College of Home Science, Saifabad, Hyderabad - 500004, India \\ ${ }^{2}$ AssociateProfessor, College of Home Science, Saifabad, Hyderabad - 500004, India
}

\begin{abstract}
Women empowerment is giving rightful power or authority to perform a task either at the household and occupational level. Decision making of women is very much important as it increases their bargaining power and promotes economic empowerment. If women are empowered they would be able to participate in the planning and decision making tasks and contribute to the development programmes and activities independently. Women's confidence and self-esteem increase when they have greater knowledge, economic assets and income-earning capacity, and they are more likely to participate in both private and public decision-making. Low participation is often due to stereotypes, which assign women's influence to the private sphere and men's to the public. The use of quotas and positive action to increase women's participation in decision-making bodies is not enough to ensure their participation, but is an important first step. This present study focuses on women empowerment with an objective to study the decision making authority at household level.Data was gathered through personal interviews using a schedule from a sample of 224 men and women in two villages of Mahbubnagar district, Telangana. The quantitative and qualitative data was collected regarding the decision making power on income, spending, savings, expenditure on purchases, children's education and marriage decisions etc. Majority of the respondents expressed having decision making authority in matters regarding the household activities.Including women in the decision making at occupational and societal level regarding the financial issues can promote economic empowerment of women at the household, occupational and society level. The study recognizes that there is a strong relationship between decision making authority and women's economic empowerment.
\end{abstract}

Keywords: gender differences, men,women, decision making, economic empowerment

\section{Introduction}

The subject of empowerment of women has becoming a burning issue all over the world including India since last few decades. In the simplest of words it is basically the creation of an environment where women can make independent decisions on their personal development as well as shine as equals in society. It is no real surprise that woman empowerment is a frequently discussed topic with no real solution coming in the prospect except to redouble our efforts and continue to reduce the sources of all the gender differences and ill-will towards women.

Gender differences in household decision-making are a common phenomenon in developing countries. It is influenced by ethnicity, culture and geographical location. In farm families, these differences are seen mostly. Though women participated in different activities at household and occupational level equally to men, their decisions are not taken into consideration. Therefore steps have to be taken to encourage, empower women and they have to be given a chance in decision making practices in household and occupational activities.

Decision making is an important factor promoting women empowerment. If women were empowered they would be able to participate in the planning and decision making task and contribute to the development programmes and activities individually at household and societal level. The objective of the study is to understand the empowerment status of women through their decision making authority for the household activities.

\section{Methodology}

An exploratory research design was adopted for conducting the study. The study was conducted in two villages namely Aurepalle and Dokur of Mahbubnagar district, Telangana, Indiaon 112 men and 112 women. Personal interviews were conducted. Qualitative and quantitative data was collected using an interview schedule.

\section{Results and Discussion}

The results in the table 1 showed that majority of the women (90.62\%) made decision on which food to cook on a particular day. Regarding the construction of house and renovation of house, majority of the households had decisions made jointly. These same conditions were seen even in the village wise analysis. On the other hand, very few percentage of men (4-6\% nearly) had the right to take own decision regarding the construction or renovation of house. This showed that women also were involved in decision making where the expenses of the work were high.

Regarding the budgetary practices, the decision on amount to be spent on consumption of food items was mostly in the hands of women (56.70), followed by joint decisions (23.22\%). The results regarding purchasing food items/ household items was mainly $(51.78 \%)$ in the hands of women, followed by male decisions $(28.58 \%)$. The results were on par with the results of the study conducted by Ngome and Angella (2003) which stated women were dominant in decisions regarding cooking, food preparation, childcare, household shopping. 


\section{International Journal of Science and Research (IJSR) ISSN (Online): 2319-7064 \\ Index Copernicus Value (2013): 6.14 | Impact Factor (2015): 6.391}

Regarding the clothing, the decisions mostly (89.28\%) were made jointly, followed by female decisions $(10.71 \%)$. The knowledge on cloth quality is greater among women; hence the decisions were taken by women even for clothes which men wore. As there was a need to go to other town for purchase of clothes, men had to accompany women and hence the decisions were taken jointly in most of the households in the case of clothing.

The decisions regarding the expenditure to be spent on education of children, the decisions were mostly taken jointly (90.18\%). These results were not in accordance with the results obtained in the study by Ngome and Angella (2003) which stated that men were dominant in deciding on the amount to be spent on children's education.

The decisions regarding the expenditure on health care of family members was mostly $(99.10 \%)$ taken up jointly. Some of the health ailments may cause heavy expenses for their treatment and this might be the reason for majority of joint decisions in this area. The obtained results were not in accordance with a study by Ngome and Angella (2003) which stated that the family healthcare decisions were taken up my women majorly.The decisions regarding the expenditure on festivals and special occasions was mostly decided jointly (70.54\%), followed by female decisions $(29.46 \%)$.

The decisions regarding the savings and borrowing loans were taken jointly in majority of the households $(80.36 \%)$, followed by male decisions $(7.14 \%)$. None of the women had control over decision making towards the sources of loans and savings, amount to be saved. The decisions regarding the purchase/ selling of jewellery or movable property were taken jointly in all the respondent households.

The decisions regarding the children's purchases, their medical treatment, age of schooling, level of education and type of institution for education were taken up jointly in majority of the households. The results were not in accordance with the study done by Ngome and Angella (2003) which found that men were dominant in decisions regarding children's education and children's marriage issues.

Few per cent of households had dominant male decisions and dominant female decisions regarding these issues. About 7-9 per cent of the households had no decisions to be taken regarding these issues as they had no children. Majority $(59.82 \%)$ of the respondents had not responded to the question regarding the decision of marriage age of their children and on expenses to be spent on marriage of children as they had no children or the age of their children were too young to decide about this matter. 1.34 per cent of the male respondents had full right to decide above this issue and none of the female had the ability to decide over this issue.

To conclude, the decisions regarding the household activitieswhich involved small issues and amounts of expenses were mostly taken by women, followed by joint decisions. Men had a very less role in the household decisions when compared to women. The role of men was high when compared to women only in the cases where huge money was to be invested. This clearly gave evidence that the respondent women's knowledge regarding financial transactions and bargaining power is good and gives an indication that they are economically empowered primarily at the household level.The results were in accordance to a study which concluded that in the matters related with home management, women had an upper hand in terms of their independent decision (Lu, 2007).The results also highlighted the need to involve women and give them an upper hand even in the decisions which involved greater expenses as this act would reduce the gender differences existing in the families and societies and empower the women economically and socially.

Table 1: Decision making in the respondent households regarding the Household activities

\begin{tabular}{|c|c|c|c|c|}
\hline \multirow{2}{*}{ Decision related area } & \multicolumn{4}{|c|}{ Total (N=224) } \\
\cline { 2 - 5 } & MD & FD & JD & Others \\
\hline \multicolumn{5}{|c|}{ Home Management } \\
\hline Cooking a particular food & 1 & 203 & 20 & 0 \\
& $(0.44)$ & $(90.62)$ & $(8.92)$ & $(0.00)$ \\
\hline Construction of a new house & 11 & 0 & 213 & 0 \\
& $(4.90)$ & $(0.00)$ & $(95.08)$ & $(0.00)$ \\
\hline Renovation of existing house & 13 & 2 & 209 & 0 \\
& $(5.80)$ & $(0.90)$ & $(93.30)$ & $(0.00)$ \\
\hline
\end{tabular}

\begin{tabular}{|c|c|c|c|c|}
\hline \multicolumn{6}{|c|}{ Amount spent on consumption } \\
\hline On food items & 45 & 127 & 52 & 0 \\
& $(20.08)$ & $(56.70)$ & $(23.22)$ & $(0.00)$ \\
\hline
\end{tabular}

\begin{tabular}{|c|c|c|c|c|}
\hline \multicolumn{5}{|c|}{ Purchasing necessary items } \\
\hline $\begin{array}{c}\text { Buying food materials/ } \\
\text { household items/ household } \\
\text { durables }\end{array}$ & $\begin{array}{c}64 \\
(28.58)\end{array}$ & $\begin{array}{c}116 \\
(51.78)\end{array}$ & $\begin{array}{c}44 \\
(19.64)\end{array}$ & $\begin{array}{c}0 \\
(0.00)\end{array}$ \\
\hline $\begin{array}{c}\text { Buying clothing and amount to } \\
\text { be spent }\end{array}$ & $\begin{array}{c}0 \\
(0.00) \\
\end{array}$ & $\begin{array}{c}24 \\
(10.71) \\
\end{array}$ & $\begin{array}{c}200 \\
(89.28) \\
\end{array}$ & $\begin{array}{c}0 \\
(0.00) \\
\end{array}$ \\
\hline \multicolumn{5}{|c|}{$\begin{array}{ll}\text { Expenditure } \\
\end{array}$} \\
\hline Education of children & $\begin{array}{c}0 \\
(0.00) \\
\end{array}$ & $\begin{array}{c}0 \\
(0.00) \\
\end{array}$ & $\begin{array}{c}202 \\
(90.18) \\
\end{array}$ & $\begin{array}{c}14 \\
(6.26) \\
\end{array}$ \\
\hline Health care for family members & $\begin{array}{c}0 \\
(0.00) \\
\end{array}$ & $\begin{array}{c}2 \\
(0.90) \\
\end{array}$ & \begin{tabular}{|c|}
222 \\
$(99.10)$ \\
\end{tabular} & $\begin{array}{c}0 \\
(0.00) \\
\end{array}$ \\
\hline Festival \& Special occasions & $\begin{array}{c}0 \\
(0.00) \\
\end{array}$ & $\begin{array}{c}66 \\
(29.46) \\
\end{array}$ & $\begin{array}{c}158 \\
(70.54) \\
\end{array}$ & $\begin{array}{c}0 \\
(0.00) \\
\end{array}$ \\
\hline \multicolumn{5}{|c|}{ Borrowing loans } \\
\hline $\begin{array}{l}\text { Decision on taking loans, } \\
\text { amount to be taken and } \\
\text { repaying the amount }\end{array}$ & $\begin{array}{c}16 \\
(7.14)\end{array}$ & $\begin{array}{c}0 \\
(0.00)\end{array}$ & $\begin{array}{c}180 \\
(80.36)\end{array}$ & $\begin{array}{c}0 \\
(0.00)\end{array}$ \\
\hline Sources of loans & $\begin{array}{c}16 \\
(7.14)\end{array}$ & $\begin{array}{c}0 \\
(0.00)\end{array}$ & $\begin{array}{c}180 \\
(80.36)\end{array}$ & $\begin{array}{c}0 \\
(0.00) \\
\end{array}$ \\
\hline
\end{tabular}

Saving and other capital transactions

\begin{tabular}{|c|c|c|c|c|}
\hline $\begin{array}{l}\text { Deciding on saving, amount to } \\
\text { be saved and sources of savings }\end{array}$ & $\begin{array}{c}16 \\
(7.14)\end{array}$ & $\begin{array}{c}0 \\
(0.00)\end{array}$ & $\begin{array}{c}180 \\
(80.36)\end{array}$ & $\begin{array}{c}0 \\
(0.00)\end{array}$ \\
\hline $\begin{array}{c}\text { Buying/ selling jewellery and } \\
\text { other movable property }\end{array}$ & $\begin{array}{c}0 \\
(0.00)\end{array}$ & $\begin{array}{c}0 \\
(0.00)\end{array}$ & $\begin{array}{c}224 \\
(100)\end{array}$ & $\begin{array}{c}0 \\
(0.00)\end{array}$ \\
\hline \multicolumn{5}{|c|}{ Child Related } \\
\hline $\begin{array}{l}\text { Deciding on children's } \\
\text { purchases and medical } \\
\text { treatment }\end{array}$ & $\begin{array}{c}8 \\
(3.58)\end{array}$ & $\begin{array}{c}9 \\
(4.02)\end{array}$ & $\begin{array}{c}191 \\
(85.26)\end{array}$ & $\begin{array}{c}16 \\
(7.14)\end{array}$ \\
\hline Deciding on medical treatment & $\begin{array}{c}10 \\
(4.46)\end{array}$ & $\begin{array}{c}9 \\
(4.02) \\
\end{array}$ & $\begin{array}{c}189 \\
(84.38)\end{array}$ & $\begin{array}{c}16 \\
(7.14)\end{array}$ \\
\hline $\begin{array}{r}\text { Deciding on } \mathrm{t} \\
\text { schooli }\end{array}$ & $\begin{array}{c}10 \\
(4.46) \\
\end{array}$ & $\begin{array}{c}9 \\
(4.02) \\
\end{array}$ & $\begin{array}{c}183 \\
(81.70) \\
\end{array}$ & $\begin{array}{c}22 \\
(9.82) \\
\end{array}$ \\
\hline $\begin{array}{l}\text { Level of education and type of } \\
\text { institution }\end{array}$ & $\begin{array}{c}17 \\
(7.58)\end{array}$ & $\begin{array}{c}9 \\
(4.02)\end{array}$ & \begin{tabular}{|c|}
176 \\
$(78.58)$ \\
\end{tabular} & $\begin{array}{c}22 \\
(9.82)\end{array}$ \\
\hline $\begin{array}{l}\text { Marriage age of son/ daughter } \\
\text { and amount of expenses to be } \\
\text { spent on marriage of son/ } \\
\text { daughter }\end{array}$ & $\begin{array}{c}3 \\
(1.34)\end{array}$ & $\begin{array}{c}0 \\
(0.00)\end{array}$ & $\begin{array}{c}87 \\
(38.84)\end{array}$ & $\begin{array}{c}134 \\
(59.82\end{array}$ \\
\hline
\end{tabular}




\section{International Journal of Science and Research (IJSR) \\ ISSN (Online): 2319-7064}

Index Copernicus Value (2013): 6.14 | Impact Factor (2015): 6.391

*Figures in parenthesis indicate percentages

$* * \mathrm{MD}=$ Male Decision, JD= Joint Decision, $\mathrm{FD}=$ Female

Decision

\section{Conclusion}

Women empowerment is giving rightful power or authority to perform a task either at the household and occupational level. Decision making of women is very much important as it increases their bargaining power and promotes economic empowerment. If women are empowered they would be able to participate in the planning and decision making tasks and contribute to the development programmes and activities independently. Women's confidence and self-esteem increases when they have greater knowledge, economic assets and income-earning capacity, and they are more likely to participate in both private and public decision-making. Low participation is often due to stereotypes, which assign women's influence to the private sphere and men's to the public. The use of quotas and positive action to increase women's participation in decision-making bodies is not enough to ensure their participation, but is an important first step. Including women in the decision making at occupational and societal level regarding the financial issues can promote economic empowerment of women at the household, occupational and society level. The study recognizes that there is a strong relationship between decision making authority and women's economic empowerment.

\section{References}

[1] LuJinkyLeilanie. 2007. Gender differentiation among farmers inthe agricultural sector inBenguet, Philippines. Journal of International Women's Studies.9(1): 41-45.

[2] Ngome and Angella N. 2003.Gender Division of Labour and Women's Decision- Making Power in Rural Households: The Case of Mbalangi, Ediki and Mabonji Villages of Meme Division.Master's Thesis, University of Buea, Department of Women and Gender Studies.

[3] Yogendrarajahand Rathiranee. 2013. Women Empowerment through Decision Making. The International Journal of Economics and Business Management.3 (1).

Volume 5 Issue 6, June 2016 www.ijsr.net 